\title{
Reflections On Feminism, Immaterial Labour And The Post-fordist Regime
}

\section{Angela McRobbie}

\begin{abstract}
In the many articles and books written in recent years on the topic of precarious labour, immaterial and affective labour, all of which are understood within the overarching frame of post-Fordist regimes of production, there is a failure to foreground gender, or indeed to knit gender and ethnicity into prevailing concerns with class and class struggle. I seek to rectify this by interrogating some of the influential work in this terrain. I draw attention to those accounts which have reflected on gender and on changes in how feminists and sociologists nowadays think about the question of women and employment. I ask the question, how integral is the participation of 'women' to the rise of post-Fordist production, and what kind of role do women, especially young women now play in the urban-based new culture industries? By prioritising gender I am also critiquing its invisibility in this current field of new radical political discourse associated with writers like Hardt and Virno (eds 1996) and Hardt and Negri (2000). I argue for a more historically informed perspective which pays attention to the microactivities of earlier generations of feminists who were at the forefront of combining forms of job creation with political activity (eg women's book stores and publishing, youth-work or 'madchenarbeit', child care and kinderladen) under the auspices of what would now be called 'social enterprise'.
\end{abstract}

1. See for example: M. Hardt and P. Virno P (eds), Radical Thought in Italy, Minneapolis, University of Minnesota Press, 1996; M. Hardt, 'Affective Labour' in Boundary 2, 26 (1999): 89-112, Duke University; M. Lazzarato, 1999, 'Immaterial Labour' $<$ www.generationonline.org/ immateriallabour3> 1999, also in Hardt and Virno (eds), Radical Thought in Italy, op. cit., p133151; M. Hardt and A. Negri, Empire, Boston, Harvard University Press, 2000; P. Virno, The Grammar of the Multitude, New York, Semiotexte, 2005.
Keywords feminism, precarious labour, immaterial labour, affective labour, Operaismo, gender and employment, post-Fordism

\section{OPERAISMO AND THE SUCCESSES OF CLASS STRUGGLE?}

In the many articles and books written in recent years on the topic of precarious labour, immaterial and affective labour, all of which are understood within the over-arching frame of post-Fordist regimes of production, there is a failure to foreground gender, or indeed to knit gender and ethnicity into prevailing concerns with class and class struggle. I seek to rectify this by interrogating some of the influential work in this terrain. I will also draw attention to those accounts which have reflected on gender and on changes in how feminists and sociologists nowadays think about the question of women and employment. (It is almost unnecessary to indicate that the critical paradigm underlying the shift in feminist debate is performativity theory and the radical de-naturalising of gender therein.) I ask the question, how integral is the participation of 'women' to the rise of post-Fordist production, 
and later in this article I ask what kind of role do women, especially young women (dispensing from now on with the need for the commas that query the category) play in the urban-based new culture industries? By prioritising gender I am also critiquing its invisibility in this current field of new radical political discourse associated with writers like Hardt and Virno, and Hardt and Negri. ${ }^{1}$ I propose that the transition to precarious work or immaterial labour which is now so profoundly felt by vast numbers of young people, especially young women, ${ }^{2}$ across Europe and under the age of 40 , is inadequately understood without recourse to a critical interface that develops from the late 1970 s onwards, between the wider impact of the women's movement (going well beyond the confines of self-declared feminists), and the modes of counter-response which capital, the state and consumer culture develop to constrain and re-shape, by means of a range of biopolitical strategies, the whole terrain of gender and sexuality.

I challenge writers like those associated with the Italian Operaismo School for their insistence on class, as the defining meta-concept for understanding contemporary work and for imagining a radical political future. Fundamentally this is a 'labour-society' model where the 'decline of labour' and the shift of the centre of gravity to the non-work sphere, is blamed for a wide range of contemporary pathologies including the 'opacity of groups' and the 'ruin of the self' ${ }^{3}$ Counter to this I would argue that the way in which class now needs to be retained, (in its always-existing entanglement with gender and ethnicity) is, paradoxically, in its decline, something which has been displaced as a primary or foundational concept. This is not quite the same as Beck's idea of the zombie concept, more a governmentally-directed shift which fades out the social and political salience of class permitting at the same time a coming forward of gender as a source of self-validation. Understanding of this as a political strategy does not negate the place of class, but it does require a different kind of thinking about class, one which focuses on this twilight status. The sustained attempts within contemporary governmentality to 'de-classify' society in the name of a gendered modernity (the New Labour strategy in the UK) have, I would suggest, had tangible effects. This is partly due to the successes of 'make-over' lifestyle television programmes, and to the growth of aspirational media and popular culture. ${ }^{4}$

This is not to say that class is irrelevant. But does it have, and can it have, quite the fundamental analytical purchase writers like Hardt, Lazzarato, Negri and Virno claim? If we agree that class is neither a sociological descriptor, nor a question of social identity, but primarily, though by no means exclusively, a set of antagonistic relations formed in the struggle between capital and labour, or between the state and subordinated social groupings whose subjugation entails a distinctive relation to labour, (for instance the unemployed), are these class antagonisms today such primary structuring mechanisms when labour comprises of subjects now much less engaged as 'workers'? And in the light of this is it these same old class relations which can somehow be re-
2. I say especially young women here, on the basis of witnessing as a teacher the enormous emotional and psychological impact these life changes have on young women. See also L. Fantone,

'Precarious

Changes: Gender and Generational Changes in Contemporary Italy' in Feminist Review 87 (2007): 5-20.

3. Virno, The Grammar of the Multitude, op, cit., p20.

4. A. McRobbie, The Aftermath of Feminism, London, Sage, 2008. I would refer readers to the recent TV series on BBC 2 where the so-called 'Queen of Shops' Mary Portas undertakes to modernise a rundown shop usually owned and managed by working class women. Mary Portas subjects these shops and their management to an extensive middleclass make-over, eradicating all signs of the past (stodgy food on sale, unkempt appearance of staff, lazy or casual attitudes of staff) and introduces a new regime which pervades the whole spatial organisation of the shop, its look and image, its products, lighting its whole 'ambience' etc. In true Bourdieusian style she instructs her subjects in matters of style, taste and distinction. 
5. I confess here to being drawn still to the post-structuralist approach to class in the work of Laclau and Mouffe and to their post-Marxist analysis of struggles and antagonism and chains of equivalence without class as a social dominant, see E. Laclau and C. Mouffe, Hegemony and Socialist Strategy, London, Verso, 1985.

6. Virno, The Grammar of the Multitude, op. cit., p14.

7. All the years of debate about the problems of class reductionism in the writing of Stuart Hall in the 1970s and 1980s and also Ernesto Laclau and Chantal Mouffe, have no place here. Nor is there any sense of a need to interrogate class as a cultural and a political signifier, a space where relations of power and powerlessness are pursued across the sites of everyday life, for example in the school playground, P. Willis, Learning to Labour, London, Saxon House, 1978; P. Bourdieu et al, The Weight of the World, Cambridge, Polity Press, 2000.

8. Lazzarato defines immaterial labour as 'the labour that produces the informational and cultural content of the commodity', Lazzarato,

'Immaterial Labour', op. cit. Affective labour is work which awakened and unleash themselves for radical change? Who exactly are the exemplary class (non)-subjects called into being by the labour process? Is it not the case that the gender or ethnicity of such subjects provides a more significant dimension in the forms and the locations of struggle ${ }^{5}$ Despite the Deleuzian moves introduced around notions of difference and becoming, as well as the use of the more capacious concept of multitudes, Hardt and Negri are locked within a class model which permits no space at all for reflecting on the centrality of gender and sexuality in the post-Fordist era, with the result that there is a failure to consider the meaning of what is often referred to as the feminisation of work. These authors insist on a high level of abstraction as they re-work terms found in Marx's Grundrisse which pertain to the abstract knowledge concretised in the machinery (and now in the computational codes) of production. This affects the relations of the workforce in the light of the increasing significance of this abstract knowledge or General Intellect. Where machines or computers do most of the productive work, the standard measure of value for the work carried out by the actual workforce is lost. Marx predicts this leads to widespread social disruption and class struggle. Virno and the others instead see new forms of cynical and opportunistic subjectivity develop not from within the workplace, but from outside, in everyday life, or in the street which becomes a site for 'urban training' ${ }^{6}$ It is the shallowness and superficiality of these states of mind which lead Virno, for example, to envisage such discontent eventually transmogrifying, through a politics of disenchantment, into new political subjectivities. But this surely relegates questions of gender and race to the realm of the less than abstract? Is there not at play here a hierarchy of abstractions which configures the 'classic' antagonism between capitalist production and its subjugated workforce as the key to understanding contemporary sociality ${ }^{7}$ It is surprising that this gender-blindness has not already attracted much attention. I would posit that this is also symptomatic of a problem which I will address later in this article, which is that in spheres of activity where it looks as though women have made considerable gains, such as the new service sector or the creative and new media industries, where they are highly visible and numerous, and where there is, to draw on a phrase from J-L Nancy, a 'sense of equality', it becomes tempting, for activists as well as sociologists, to succumb to the wider current of opinion which is that gender is no longer a 'problem' implying that there is no particular need for a renewed feminist critique.

First let me consider some of the key arguments in Radical Thought in Italy, and in Empire. This work has been so profoundly influential in recent years that it stands at the centre of current debates on work and on the idea of 'immaterial labour' as a distinctive feature of the post-Fordist regime. ${ }^{8}$ Throughout this writing the theoretical framework is shaped by a nondialectical (and hence non teleological) post-Marxist concept of class which is injected with a powerful sense of capacity and agency through re-thinking class action with recourse to the Deleuzian notion of desire which, so claim the 
authors, is generative, producing waves and multiplicities of opposition and resistance to capital's oppressive and exploitative practices. It is this idea from Deleuze which permits a form of class agency without an agent, and without the identity politics which suggests a stable subject as the holder of such an identity. There are three innovative elements here: first, a decisive attempt to project forwards in the context of the defeats of the Left in Italy and to imagine and envisage new potentialities for radicalism through dissecting what Virno calls the 'emotional situation' characteristic of contemporary subjectivity; second, this possibility for radicalism is based on a subject-less form of class politics, now configured as flows, as lines of flight, and as events; and third while fully confronting the scale of defeat through the 1980s, years which according to Virno saw the growth of a celebratory postmodern lifestyle, there is in this work a deliberate attempt to reinstate a sense of victory over the capitalist machine. This is surprising, sometimes exhilarating and in sharp contrast to the prevailing wisdom across sociology and political philosophy in the last 30 years in the light of the dramatic decline of class politics, the rise of Thatcherism and then of New Labour in the UK, and of brands of neo-liberalism across Europe and of course triumphantly in the US. ${ }^{9}$ Wendy Brown, Stuart Hall and Nikolas Rose (among others) have examined the forces (e.g. the role of media) which were orchestrated to discredit labour activism and to demonise left as well as feminist and anti-racist movements. Whether through campaigns, or through policies and ideas emerging from new right think-tanks, these authors point to the attempts to de-legitimate trade unions, to undo the field of welfare provision and in effect to dismantle the social field. They look at how individual responsibility now takes precedence, with a whole raft of policies designed to improve the conduct of persons and supplant welfare regimes. Such forms of biopolitics re-stratify society in more complex ways than before, while at the same time ensuring the maintenance of existing social hierarchies. Aggressive neo-liberalism entails an assault on the resources and agencies which have defended working class interests to the point that these have been more or less destroyed.

It is the idea of potenza which gives the authors in Hardt and Virno ${ }^{10}$ as well as Hardt and Negri in Empire the possibility to envisage 'decentralised or mass conceptions of force and strength' able to challenge capital to the core. ${ }^{11}$ They see post-Fordism as a response on the part of capital to these potenza struggles of the working class through the 1960s and 1970s. They repeatedly cite the 'refusal of work' on the part of the young factory workers (in Italy and France) who would not conform to labour discipline, and they talk about the exit from the factory. More specifically they see capital as having to make concessions (or give some ground) such that, with better wages in their pockets the working class expresses new desires, new dreams of lifestyle. Likewise young working class people declare their wishes for a different and better life. ${ }^{12}$ Capitalist production increasingly needs a higher degree of cognitive capacity or brain power (mass intellect) from its workforce than was requires high levels of intimacy, care, or emotions.

9. For example Stuart Hall's work on Thatcherism and then on Blairism, see S. Hall and M. Jacques, The Politics of Thatcherism, London, Lawrence and Wishart, 1983; S. Hall 'The Great Moving Nowhere Show' in Marxism Today 1998 special issue http://www. amielandmelburn. org.uk/collections/ $\mathrm{mt} / \mathrm{pdf} / 98 \_11$

09.pdf, and Wendy Brown on neo-

liberalism, W. Brown, 'Neo-Liberalism and the End of Liberal Democracy?' in Theory and Event 7, 1 (2003), and reprinted in W. Brown, Edgework: Critical Essays in Knowledge and Power, Princeton, NJ, University of Princeton Press, 2005. See also L. Boltanski and E. Chiapello, The New Spirit of Capitalism, London, Verso, 2007.

10. Hardt and Virno (eds), Radical Thought in Italy, op. cit., 1996.

11. Ibid., p262.

12. At which point we could signal some overlap with Birmingham CCCS studies of workingclass youth culture carried out in the mid to late ' 70 s and early 1980s and thus concurrent with the activities analysed by Hardt and Negri, although of course the concept of culture for the CCCS writers had a great deal more 
political significance, see S. Hall and T. Jefferson (eds), Resistance through Rituals, London, Hutchinson, 1976 So where Hardt and Negri focus on work, Birmingham CCCS look to leisure. In addition class politics in the Birmingham work was realised primarily in the symbolic fields of fashion, music, style etc with the result that trade unions, shopfloor politics, work, employment and organised parties of the left were largely overlooked with the exception of Paul Willis, Learning to Labour, op. cit.

13. S. Lash and J. Urry, The Economy of Signs and Spaces, London, Sage, 1994.

14. Hardt and Negri, Empire, op. cit. the case in the past. One of the putative concessions granted was that work could become more meaningful and that the workforce could be allowed to act more autonomously in the workplace and have a greater decisionmaking capacity. Such a dispensation or permission-to-think segues into the transition to post-Fordist technology and new forms of communications and information-based production. The combination of this brain power along with new communications technology means that capitalism is able to deliver high degrees of customisation and design in its commodities to increasingly diverse and lifestyle-conscious groups of consumers including the now more mobile working class. The successes of the class struggle result in higher wages and a more participatory and intelligent role in the workplace.

These authors emphasise how capitalism was forced to concede to the workers' struggles of the 1970s. The more usual account is that it was under pressure from rising wages at home and the competition from developing countries with ample supplies of cheap labour that First World global companies, from fashion and furniture to car production and food, embarked on a transition to post-Fordist production. To regain dominance the big corporations must provide novelty and innovation in goods and commodities and lead in the world of design and lifestyle, so that affluent consumers can be flattered in knowing themselves to be distinctive from their peers and counterparts on the basis of being able to purchase goods which are made only in small quantities (or batches) and hence more valuable because of this idea of rarity or high levels of 'design intensivity'. ${ }^{13}$ The Operaismo writers offer a different perspective which foregrounds the agency of the labour force and the changing nature of work. This is inarguably important, as is the focus they provide on the ways in which young people expressed a desire to 'exit the factories'. In Italy capital was forced onto the defensive, as fewer younger people were willing to subject themselves to labour discipline. Jobs had to become more attractive to workers, for them to be willing to perform these tasks. Post-Fordism is then an incorporative strategy and capital is weakened because having given way in certain respects it finds itself reliant on the mental capacities of the workforce in an unprecedented way. And because the workers are able to exercise their brains thereby achieving a kind of autonomous space for critical thought and reflection, they are in a profound sense uncaptured by the dogma and dictates of contemporary power, and capital lags behind them, increasingly dependent on their ideas and initiatives.

These mental capacities produce a disposition towards co-operation and collectivity, qualities which are also required in the new workshops or studios of cognitive capitalism. 'Today the production of wealth requires cooperation and interactivity'. ${ }^{14}$ The workers now need to talk to each other and make joint decisions; they can argue and express their opinions as to how a commodity needs to be produced or a service provided. With this quality of interaction, the working class are therefore now better able to re-imagine solidaristic forms of mutual support and co-operation. Lazzarato points out that the workers can 
now also become entrepreneurs themselves, no longer must they be seen only as employees and as mere wage labourers and of course this chimes well with the growth of freelance or precarious self-employment among young people or with new forms of micro-entrepreneurialism associated with the growing cultural and creative and media sectors of advanced capitalism. ${ }^{15}$ But there are fine lines of difference between the Operaismo writers as to how far this potenza can be stretched to envisage such possible forms of communality or 'commons'. There is a discrepancy between the contributions of Hardt and Negri and Lazzarato, and the darker comments from Virno and Berardi. Joyful ideas of communality and even communistic sentiments are countered by a powerful regime which inculcates cynicism and opportunism, manifest in the context of the party and events culture of network sociality where selfpromotional public relations holds sway. This cultural milieu of small talk and endless parties exasperates and horrifies Virno pushing him, and then Berardi also, to refer to the psycho-pathologies of contemporary subjectivity. ${ }^{16}$ With the tight lines between work and leisure dissolved, with spare time taking on the urgency of working time, they see this party culture 'vibe' and its subjective states as being transferred into the workplace, infecting it. ${ }^{17} \mathrm{We}$ might stop here for a moment and reflect on this interesting observation. Are these pathologies also gendered? How do young men and women experience distress differently in their attempts to make an independent living in these new informal fields of work? Or even in the institutions of higher education where the short contract is also normalised? Might these emotional states tipple over into anger and rage and opposition to the etiquette required of the public relations machine? This is implicit in the Operaismo writing but it remains under-developed. How would such affective states be analysed?

\section{FEMINISATION OF WORK?}

Hardt and Negri in Empire rely on an expanded concept of working class which becomes 'multitudinous' and no longer tied to specific nation states, thus including migrants and refugees moving across continents in search of a better life. While the women's movement is fleetingly referred to for the role it played in disrupting the nuclear family and thus interrupting the reliable supply of youthful labour (presumably by encouraging women to have fewer children), this emphasis on women's prime responsibility for reproduction is not updated. Indeed most academic feminists from across the social sciences would throw up their arms in protest against this kind of class-dominated and gender-essentialist account of the changing world of work. Despite possible openings to gender within the multitude, gender is subsumed into class, as is race and ethnicity, and feminists like myself experience a kind of flashback to moments where women could only legitimately be considered if cast in the language of either domestic labour or reproduction. As Gayle Rubin reminded us, Marxism (even Marxist-feminism) was simply not able to
15. Though it is not all so new, in the late 1980 s I drew attention to the way in which young people involved in youth cultures, often from working class backgrounds and not destined for universities, became subcultural entrepreneurs in a bid to combine what they enjoyed doing inside the youth culture with a way of making a living from those same activities and hence avoiding unemployment, A. McRobbie, 'Second Hand Dresses and the Role of the Ragmarket' in K. Gelder and S. Thornton (eds), The Subcultures Reader, London, Routledge, 1997 (1989). And writing by Sergio Bologna not available in English argues there is a shift in the point of exploitation for the self-employed or the new small entrepreneurs who are now beholden to banks for loans to underwrite their enterprises (personal communication Tiziana Terranova).

16. P. Virno, The Grammar of the Multitude, New York, Semiotexte, 2005; F. Berardi, Precarious Rhapsody,London, Minor Compositions Press, 2009.

17. See Andrew Ross, No Collar: The Humane Workplace and its Hidden Costs, PA, USA, Temple Univ Press, 2004. 
18. G. Rubin,

'Thinking Sex:

Notes for a Radical

Theory of the

Politics of Sexuality' in Carol Vance (ed), Pleasure and Danger, London, RKP, 1984

19. P. Gilroy, There 'Aint No Black in the Union Jack, Basingstoke, Macmillan, 1987.

20. For an account of this shift from a perspective which pitches middleclass feminism against the interests of the industrial working class see an overlooked article by Anne Oakley and Juliet Mitchell. Their argument, betraving an ambivalence to feminism for what it is deemed to have done to the working class struggle, is very different from the one I am making here, see J. Mitchell and A. Oakley, Who's Afraid of Feminism? London, Penguin, 1986. understand and critically engage with the wider questions of sexuality which at the time resonated across the many spheres of everyday life including work. ${ }^{18}$ The centrality of Deleuzian desires, corporeality and libidinal flows, does not solve this problem: quite the opposite. The idea of multitude may well be broader and more capacious than class, now defined as a kind of everyman or everywoman category, but for all intents and purposes it remains synonymous with class.

This account of post-Fordism produces some intractable problems. First the concept of class while seemingly ungendered is in fact implicitly masculine and white. The sites of most of the struggles referred to are traditionally male sectors such as car assembly lines and the related activities associated with the automobile industry, and the industrial militancy, which the writers argue created the crisis for capitalism, took place once again in largely maledominated sectors including in the UK the coal-mining industry. Even when the authors refer to the black struggles in the US in the '60s they focus on the car assembly lines again and not on the community which was the nodal point for Civil Rights, an argument which runs counter to almost all accounts of this movement. ${ }^{19}$ The refusal of work and the exit from the factories was a primarily white male activity. During the '60s and '70s across western Europe and in other affluent countries working-class women were concentrated in part-time jobs and in white collar work, while their middle-class counterparts only began to enter the labour market in significant numbers from the late 1970 s when full time jobs in the professions and public sector became favoured locations for women especially those who wanted to continue working while also having children. The lower level of trade-union membership on the part of working-class women and the sexism and racial exclusions of the unions themselves meant that only on a few occasions did working-class and black women become involved in industrial conflicts. And the main changes which improved the conditions of work for women from the mid 1970s were the result of campaigning by the various sectors of the women's movement for equal pay and for anti-discrimination legislation.

On what grounds is it then convincing to talk about the gender of postFordism? I would propose that a significant element in the shift to postFordism was the expansion of the possibilities for women's employment across many countries and particularly in the affluent countries where there had been a strong feminist movement through the 1960s arguing for gender equality and for the right to work and thus for women to be no longer economically dependent for their survival on a husband. The women's movement reached a peak in the years which coincided with the crisis in profitability for many major companies across the world. And since the structure of patriarchal society at that time had produced gender-segregated labour markets with men generally occupying the better paid and more highly skilled industrial jobs, the shift to a post-industrial economy adversely affected the employment prospects for working class men while having the opposite effect for women. ${ }^{20}$ 
The nature of work in a post-Fordist economy favoured the large skill pool and the flexibility of the female workforce. In the UK women flowed into work from the mid-1980s and have continued to do so ever since. The UK has seen the growth of post-Fordist techniques of production in various sectors, i.e. retail, fashion and clothing, furniture and household goods, DIY, and a huge service sector which booms especially in London and the South East as London became a global city and centre for the finance industry through the 1980s. A combination of the impact of feminism and the sexualrevolution providing birth control and wider opportunities to women mean that the aspirations of young women have grown exponentially from the late 1970 s onwards. Increasingly they could earn their own living and achieve a disposable income which in turn meant being able to enjoy leisure and the freedoms of movement which the delay in age of marriage and delay in having children created, i.e. holidays and travel. This leads to a feminisation of the workforce, such that we can begin to see a close correlation between women's increasing independence and the growth of post-Fordist production processes. What is decisive is participation in employment. And as women are more present in the workplace new goods and commodities become available catering for the needs of the working woman rather than the mother at home. As Sean Nixon points out the fashion retail Next set up in the early 1980s offers a perfect example of fashion with high-design content targeted towards the new style-conscious and aspirational white-collar worker. ${ }^{21}$ What seems to start with Next in the UK, expands across many products and goods leading twenty years later to a global rise in spectacular consumption, for which women serve as the main market.

Women have historically been positioned as the domestic decision-maker in the purchasing of goods and services, this is integral to the traditional role of housewife, but as housewifely activities are commoditised and transformed into services owing to women abandoning the stay-at-home role in favour of work, a spectacular sphere of feminine consumption emerges. This relates to the new independent disposable income women have to spend on themselves and it is this income which explains the exponential growth of the female beauty, cosmetics, fashion and media industries in the last twenty years. These sectors, also organised along post-Fordist lines, target women consumers relentlessly, dipping down into the early years of childhood to attract small girls from the age of 3 or 4 upwards into the values of so-called female pampering and body maintenance. Consumption becomes an archetypal female leisure activity, often carrying with it a kind of faux feminist legitimacy. It is coded as a new kind of women's right or entitlement on the basis of having become a wage earner and thus of having gained certain freedoms (as the famous L'Oreal advert says 'because I'm worth it').

This phenomenon can be seen across the first world, and also extending into the developing world. The flow of women into work goes hand-in-hand with the expansion of further and higher education and the flooding into

1. S. Nixon, Hard Looks, London, Routledge, 1993. 
22. B. Skeggs,

Formations of

Class and Gender,

Routledge London, 1997.

23. A. McRobbie, The Aftermath of Feminism, London, Sage, 2008.

24. Z. Bauman, The Individualised Society, London, Polity Press, 1990 . the universities of young women in increasingly high volume through the 1980s and onwards to the current moment. Where in the mid 1970s only a tiny trickle of middle class young women went to university, thirty years later girls outnumber boys in their take up of university places and in some universities there are twice as many females as males. Across Europe and the US and other affluent countries it has become normal for women in their $30 \mathrm{~s}$, and 40s today to have much higher qualifications than their mothers. Young women from working class backgrounds have taken up the opportunity to train and consequently make their way up through the ranks of various administrative and institutional sectors including the public sector, health, education, welfare, as well as in the new financial services such as insurance. Young black and Asian women across different socio-economic backgrounds seek higher qualifications and better paid work. With all of this activity inevitably there is a corrosion of the old core of working class people, as the young men (of the Hardt and Negri argument) who were in the factories in the 1970 s, thirty years later, face early retirement or redundancy. It is widely accepted that during these years in the UK and elsewhere (e.g. Germany, Italy, France, the US) there have been processes of class de-alignment, class fragmentation and new forms of social divide based on more acute polarities of poverty and unemployment on the one hand, and relative affluence on the other hand. Women come to embody processes of mobility and transition. Some take on extra work because their husbands are made redundant, some black women, mothers and daughters alike, are the main breadwinners because the labour market continues to discriminate against their fathers and brothers in specifically gendered ways. And, as Skeggs points out in the UK, within an aggressively conservative culture, white working-class women are made to feel that their low-class status jeopardises their success in the stakes of femininity and sexuality. ${ }^{22}$ White working-class femininity is associated with failure, and as a result working-class women increasingly feel they need to identify with a more aspirational and glamorous femininity made available in profusion across the world of media, on TV and in magazines in particular. ${ }^{23}$ To be properly feminine they must seek middle-class respectability, or else jeopardise their status and sexual identity as modern working women. This shows clearly how gender is made to articulate directly with the wider individualisation processes so as to diminish or reduce the significance of social class in everyday political discourse of women. ${ }^{24}$

Skeggs's work shows how working-class femininity has become a site for intensive governmental intervention. The demonisation and moral panic demonstrate the extent to which neo-liberalism requires a passive, deferential and seemingly upwardly mobile working class with women constantly appealed to as agents for this change. Thus class remains a powerful source of social anxiety, but, and this is at the heart of my response to the Operaismo writers, if working-class young women en masse through media and lifestyle are exhorted to dis-identify with a working-class position, if in 
the jobs they do such as retail manager in fashion shops like Karen Millen or Warehouse, there is no tradition or prospect of trade unionisation, but there are possibilities for further education and 'lifelong learning', is it not the case that by and large capital and the state have succeeded in producing a relatively quiescent and aspirational female workforce in this respect, so that the envisaging of opposition or of organisation within the field of work is recklessly optimistic? At the same time are there not other sites in the lifeworld where such women are more likely to become politicised, such as schooling for their children, nursery provision, health provision, care for the elderly, crime, improvements in social housing, breast cancer awareness, environment, pressure group politics etc? In this sphere, what Beck calls 'life politics', women are increasingly involved as patients, as family members, as concerned parents, or as mothers for example in groups like 'mothers against gun crime'.

\section{AFFECTIVE LABOUR?}

In the last few years there has been a lively debate on affective and immaterial labour where the focus is (implicitly or explicitly) on women but where there is either an absence of a feminist perspective or else a reliance on vocabularies which, while prevalent in late 1970s Marxist-feminist debate, are now exhausted and in need of revision. Many of these writers take the lead from Hardt, Negri and Lazzarato and this might well explain why gender is not prominent. As an extension of the discussion in the previous section I suggest that it does not make sense to interrogate the post-Fordist field of immaterial labour without foregrounding gender. Without a reflexive and upto-date feminist theory, the work, for example, of Wissinger, ${ }^{25}$ Neff, Wissinger and Zukin, ${ }^{26}$ and to a lesser extent Weeks, ${ }^{27}$ presents an often de-politicised and even celebratory account of the contemporary meaning of affective and immaterial labour in the fashion and beauty industries, and more generally in the service sector. While this celebratory tone may tally with the possibilities optimistically envisaged by the Operaismo writers (here we see the danger of adopting a left-optimist position), the weaknesses in this work are apparent. Hardt, Negri et al can hardly be blamed for work which selects aspects of their thinking while overlooking the tradition of class struggle and revolutionary politics which is so central to this oeuvre. Notwithstanding this, the visibility of debates about vitality in the terrain of immaterial labour, along with a polemic about post-Fordism being the 'communism of capitalism' (the sociality of the mass intellect prior to 'capitalist valorisation' and the market), can mean that it is relatively easy for other writers to draw on this language in a naive celebration of the vitality and apparent proto-communism of contemporary economic forms, while ignoring the aggressive neo-liberal underpinning of immaterial labour and the forms of biopower which shape up amenable kinds of subjectivities, giving rise to a new kind of society of control. This gets lost
25. E. Wissinger, 'Modelling a Way of Life: Immaterial and Affective Labour in the Fashion Modelling Industry' in Ephemera, 7, 1 (2007): 250-269; E. Wissinger, 'Modelling Consumption' in Journal of Consumer Culture 9 (2009): 273-295.

26. G. Neff, E. Wissinger and S. Zukin, 'Entrepreneurial Labour Among Cultural Producers:

"Cool" Jobs in

"Hot" Places' in Social Semiotics 15, 3 (2005): 307-3.

27. K. Weeks, 'Life With and Against Work' in Ephemera, 7, 1 (2007): 233-269. 
28. See R. Braidotti, Transpositions, Cambridge, Polity Press, 2006 for an analysis of cracks.

29. T. Terranova, Network Culture: Politics for the Information Age, London, Pluto Press, 2004.

30. Wissinger, 'Modelling a Way of Life', op. cit.

\section{Wissinger, 'Modelling Consumption', op. cit.}

32. Neff et al, 'Entrepreneurial Labour', op. cit.

33. Wissinger, 'Modelling a Way of Life', op. cit., p255. where attention is concentrated on the putative creativity of the multitude. The Operaismo writers envisage a new politics of immanence where the cracks are the moments or events of becoming, the times of uncaptured zealousness of co-operation. These are however only glimpses, flashes, cracks or moments within a landscape of capitalist domination, which entails new levels and forms of submission. ${ }^{28}$ Where such flashes of co-operation are further developed in for example Terranova's analysis of the peer-to-peer gifting and the development of open-source software within online activist communities, this is very different from attributing radicalism to creative practices and network sociality per se within the new cultural industries. ${ }^{29}$

In an article in Ephemera and published alongside other familiar authors working in the affective labour terrain Wissinger reports on her ethnographic study of high end models in New York who are signed to one of the best known agencies in the world, (associated with names such as Kate Moss). ${ }^{30}$ To most sociologists and feminists such a category of work would be designated as an elite career within the lucrative sector of the media and entertainment industries, making such work comparable to that of highly successful actors. In this article, as well as in a more recent one in the Journal of Consumer Culture, Wissinger says that this modelling is 'usually well paid' and she provides figures which point to astronomical earnings on the part of some of the most famous super-models. ${ }^{31}$ The point however is that she makes a claim for this as precarious work which is fully within the framework defined by Hardt and Lazzarato and others. The models 'perform emotional labour': they 'create community' with 'feelings of vitality and aliveness'. They are exemplary of young urban creative workers: they must invest in their looks on and off the job; they have to go to parties; and they have to 'dress the part'. In another article written with Neff et $a l,{ }^{32}$ Wissinger again sees New York models as contributing to the 'cool status' of urban cultural neighbourhoods, where they are in effect forces of regeneration. The authors seem here to be suggesting that models have been perhaps unfairly left out of the current debate about precarious labour in the new creative sectors and they want to redress this absence. However they struggle to persuade the reader as to the plight of 'high end' models, especially when saying that they are 'less mannequins than they are CEOS of their own corporations'. ${ }^{33}$

Wissinger does note that 'gender is outside the scope' of the first article referred to above, and I would say that this discounting of gender is just one of the oversights in this work which leads to generalisations and misperceptions in the realm of class, status and gender. What emerges is a paradoxical situation where top models can be seen as simultaneously part of the new expanded proletariat whose creativities have the chance of being unleashed for good social (or communistic) purposes, and at the same time are extremely wealthy entrepreneurs. I find myself in a double-bind here, having argued against the centrality of class struggle in the Operaismo work, I now find the version of the Operaismo work adopted by Wissinger and others 
to have an unrecognisable idea of class, which would locate high status fashion models as part of a new proletariat, on the basis of this being irregular and precarious work. And which also takes the job of modelling to exemplify the rise of affective labour as though it was comparable with social care work. Had Wissinger paid more attention to the role of female models and the image industry in the creation in the last two decades of the feminised and hyper-sexualised consumer culture, we might have gained better insight into the pivotal place of (mostly young) women as consumers and producers in the global corporations of the fashion and beauty complex. And likewise a feminist analysis would surely examine the way in which neo-liberal postfeminist popular culture, in the context of the potential for growth of the female consumer market, elevates, once again, in a context where feminism is considered 'uncool' or out of date, the glamour and fantasy of modelling so that, more so than before, it becomes once again a dream job (unrealisable of course) for young girls across the world, at the expense of well-paid nontraditional occupations like engineering now considered undesirable through association with late 1970 s feminism, or else more socially valuable jobs in, for example, youth and community work which have lost their status in recent years. In the same journal issue of Ephemera as Wissinger, Weeks provides a feminist response to the debate on affective labour. ${ }^{34}$ This entails a thread of connection between the early Marxist-feminist focus on domestic labour combined with an analysis of the classic work by C. Wright Mills on whitecollar work and on the requirements of specific types of personality for this new service sector. Weeks updates this by looking at the classic study of flight attendants by Hochschild. In both of these cases the role of emotional labour is re-visited: as Weeks points out, in C. Wright Mills such a display of a caring or attentive personality is considered as somehow an act, a requirement of the job requiring practised insincerity, whereas by the time of Hochschild's study the suggestion is that to be able to perform in this highly attentive and personable way, the flight attendants must somehow take on and inhabit positively that role. ${ }^{35}$ The service sector produces and requires new affective subjectivities in the workplace. Weeks stops short however at inquiring as to the political consequences of such 'emotional tonalities' ${ }^{36}$ She acknowledges that traditional essentialist understandings of what constitutes women's work have now been superseded. This occurs first because men now also do these jobs, so the work itself is less gender-segregated, and second, influenced by performativity theory, she points out that gender is actually itself created in the doing of such jobs. Femininity is produced, repetitively, in the specific circumstances where it is performed as a normative requirement of the job. Attempting to make sense of the gendered nature of work in the post-Fordist regime Weeks quotes Haraway who talks about both the 'erosion and the intensification of gender'. While Weeks recognises the fading of the field of women's work per se, as a set of hermetically sealed jobs, occupations or careers, she does not use this occasion to examine the re-framing of women's
34. Weeks, 'Life With and Against Work', op. cit.

35. A. Hochschild, The Managed Heart: Commercialization of Human Feeling, Berkeley, USA, University of California Press, 1983/2003.

36. Hardt and Virno, Radical Thought in Italy, op. cit. 
37. See R. Gill,

'Technobohemians of the new

Cybertariat', <www.

lse/collections/

genderinstitute>, 2007; L. Fantone,

'Precarious

Changes: Gender and Generational

Changes in Contemporary Italy in Feminist Review 87 (2007): 5-20; E. Blimlinger, 'The Gender of Precarity or the Feminisation of Work' in Grzinic and Reitsamer (eds), New Feminism: Worlds of Feminism, Queer and Networking Conditions, Vienna, Locker Press, 2008, pp160-172.

38. Fantone, 'Precarious Changes', op. cit., 2007. position in the field of flexible work, to highlight a situation of almost complete reversal, from the margins and from the reserve army of labour to the mainstream, and to the heartland of new forms of work. Where women's centrality to contemporary production could mark out the contours of a new form of gender power, this political potential is decisively pre-empted by the intense forms of biopolitical governmentality which constantly address women and their bodies (through media and magazines in particular) so that earning power is inextricably tied up with consumer culture and the promises of personal satisfactions therein.

\section{THE GENDER OF PRECARI TIÉ?}

A number of themes characterise the recent investigations within feminist sociology and cultural studies of young women's participation in the new cultural and creative sectors. ${ }^{37}$ First, that these are highly educated young women, mostly graduates. Second, they are the beneficiaries of second-wave feminism. Although the impact which feminism has had is known to them as a kind of common sense, few of them seem to be openly political or selfdefining as feminists. (The exception here is the new feminist movement of small groups organised around 'precari tié' in Italy described by Laura Fantone $^{38}$ ). Third, large numbers have no children or are deliberately delaying having children because of the high degree of uncertainty or precariousness in their freelance of micro-entrepreneurial activities. Fourth, although there is evidence of success in these creative fields and there are many expressions of enjoyment of the work, indeed passionate commitment to it, these freelance careers, or the experience of being a small scale entrepreneur, seem to be characterised by constant change: even within the space of a year or two many of these young women will be doing something quite different. Fifth, the women in these studies seem to be predominantly white. Some might argue that, already saddled with student loans to pay back, it is only already privileged and thus mostly white young women, who will be confident enough to take on more bank loans to start off a creative business, although there are always a few exceptions. Sixth, the aim to be self-reliant, to be running one's own small creative enterprise cannot be separated from the kind of training and education prior to this entrepreneurial activity. Art school education has long encouraged graduates to aim for their own studios and for freelance jobs and projects. So in a sense the real change is that this is more systematic, it is more crowded, as more and more graduates enter this kind of work, and it is much more visibly female as more young women complete degrees in colleges and universities. Seventh, and finally, access to further and higher education changes the class composition of the young women who are now able to take advantage of these resources. Female graduates are now socially more diverse than before, which is not to say that there are not still in place mechanisms (such as those of social capital) which advantage those from 
wealthy or securely middle-class families.

The issues raised by Larner and Molloy ${ }^{39}$ in their account of the new generation of women fashion designers from New Zealand are important for the reason that they see these young women as cultural entrepreneurs of the type considered essential to the growth of the creative economy in cities across the world. In addition they recognise that this kind of work has been made available thanks to earlier feminist struggles for opportunities for women in business. The designers have been supported by the New Zealand government in an attempt to build up the sector and showcase it globally. These are highly qualified women who are key agents in the new creative sector and the authors point out that their study shows that the feminisation of the workforce does not invariably mean lower wages and working one's way 'to the bottom of the global economy'. They produce clothes for 'other busy working women' and their career profile includes being self-employed, working for small firms, in their own start ups, or multi-tasking and going from one project to the next. The larger question which is unresolved is however that of what a feminist politics of women's entrepreneurial activities ought to be ${ }^{20}$ There is slippage in this account, rather than a confronting head-on of the reality of post-Fordist flexibility, along with enterprise culture as a recent mode of governmentality, both of which in the last decade become speededup and intensified by the gains of neo-liberalism in political culture.

What does it mean when more and more young women become small-scale cultural or creative entrepreneurs? Does this mark the kind of extension which Lazzarato points to in regard to the logic of the post-industrial landscape of employment, which would mean such actors are to be considered more like other precarious workers, a new kind of creative freelance proletariat? ${ }^{41}$ And, following the above discussion, is Lazzarato correct in this respect: can we talk about young creatives in these terms? Or are these enterprises to be considered more conventionally as small businesses often employing just a handful of people, which nevertheless means that the women owners are in effect company directors? Larner and Molloy shift around this terrain by referring to a women's way of doing business which it is implied is somehow less aggressive, perhaps more ethical. These authors see a coming together of earlier feminist struggles with new government policies resulting in the production of 'gendered neo-liberal subjectivity'. But the reader is left unsure as to what to make of this, since the enterprises and the achievements of the designers are seemingly lauded, while the neo-liberal dimensions come to be merely expressed in the design work itself as 'edgy, dark and intellectual'. Is the 'gendered neo-liberal subjectivity' a good or a bad thing? Has the creative economy been good or bad for women? Are they ambassadors of this new capitalism? Or are they simply flexible workers in the new creative economy, in the 'permanently transitional' job market which has been the subject of extensive attention in recent years, where self-employment (or freelance work or even cultural entrepreneurship) is something quite different from being a

39. W. Larner and H. Molloy, 'Globalisation, the "new" economy and working women: Theorising from the New Zealand designer fashion industry', in Feminist Theory 10 (2009): $35-59$.

40. See also A. Gray, 'Enterprising Femininity: new Modes of Work and Subjectivity " in European Journal of Cultural Studies, 6, 4 (2003): 489-506.

41. Lazzarato, 'Immaterial Labour', op. cit. 
42. A. McRobbie, British Fashion Design, London, Routledge, 1998.

43. For example Gill, 'Technobohemians', op. cit; Fantone, 'Precarious Changes', op. cit., Blimlinger, "The Gender of Precarity', op. cit.

44. L. Adkins, Revisions: Gender and Sexuality in Late Modernity, Bucks, UK, Open University Press, 2002.

45. Gill,

'Technobohemians', op. cit; C. Scharff (forthcoming), Repudiating Feminism, Ashgate, Kent.

46. Berardi, Precarious Rhapsody, op. cit.

conventional employer ${ }^{342}$ Larner and Molloy suggest that there has been too much emphasis on hardship and failure, in work such as my own, but later in the same article the authors also describe similar problems experienced by their New Zealand cohort, actually confirming the claims of this earlier work that art-school trained independent fashion designers are less CEOs, and more like conventional artists trying hard to make a living on a DIY or cottage-industry basis, constantly looking for small amounts of investment and haunted by the fear of having to give up their own work.

In the last few years there has been a spate of articles which explore the way in which gender hierarchies are re-established in the new creative and mew media sector. ${ }^{43}$ Lisa Adkins for example shows how small scale entrepreneurship often entails married couples working alongside each other, and with this she points to the almost inevitable resurrection of old gender divides in such micro-businesses, with the man being more mobile and able to travel and network while the woman, especially if there are children, will focus on the support and backroom role. ${ }^{44}$ This leads Adkins to talk about re-traditionalisation with conditions for such women as these worsening in contrast to what they might expect in a normal paid job with set hours and legal entitlements in regard to family life. In the new creative sector and in many sectors of professional life there is a veneer of equality on the basis of the sheer volume and presence of young women with good qualifications and with huge amounts of energy and drive. However, as both Gill and Scharff point out, the informal conventions of network sociality in fact negate the relevance of legal entitlements associated with 'normal work'. ${ }^{45}$ This makes it difficult for questions about sexism or racism to be raised. Instead there is a privatisation of grievances or, as Scharff argues, young women begin to see sexism as simply another obstacle which, by sheer grit and determination, they must be able to overcome individually. Nothing, she claims, is more 'uncool' than appearing to be a feminist in these workplaces. It is this same privatised and deeply individualised culture which gives rise to intense forms of mental stress, breakdown and dependence on drugs or alcohol. ${ }^{46}$ These processes point to some of the complex ways in which it seems young women have gained equality of sorts, where in reality this is undermined by subtle forces of patriarchal retrenchment implemented through the seemingly harmless but in fact ruthless and tyrannical deployment of 'cool' as a disciplinary regime in work and leisure.

There is a tension across the Operaismo work which remains unresolved: this relates to the insistence on the centrality of the workplace for the formation of new radical politics. The writers recognise that there is no longer a sharp divide between working life and everyday life including leisure. They bemoan the corrupting values of the hedonistic everyday life which are brought into 
the fields of precarious labour so that work becomes an extension of social life. They do not disavow the political importance of everyday life and other social institutions, but the movement of their analysis follows a line from the workplace outwards to the 'social factory'. This workerism/factoryism is, I would argue, counter to the most influential radical thought across the social sciences and humanities in recent years where other sites are invested with just as much political meaning as the factory floor. Such sites are deliberately not labelled as factories for the very reason that this implies a hierarchy and a pre-eminent place for wage labour and class politics. Schools, communities, streets, urban environments, prisons, the domestic space, sexuality, the fields of popular music including those of 'black expressive culture', the arts: these have been recognised as institutional spaces which are also sites of power, contestation and for the formation of critical and oppositional movements, especially for sectors of the population (generations of black and Asian people excluded from regular jobs, women reliant on part-time work) to whom paid work and careers have been inaccessible. Gilroy in the final chapter of 'There Aint No Black in the Union Jack' decisively outlined such a move away from the social determinism of the factory floor, ${ }^{47}$ and post-colonial studies, cultural studies as well as feminism, by and large have followed his lead.

The question then is, how do feminists working in cultural studies and sociology return to the workplace? With what kind of critical vocabulary is it possible both to move on from past discussions of 'women and employment' and fully to engage with new forms of precarious work which are emerging, in a sense, on top of the older forms experienced by most women across the boundaries of ethnicity and class? The authors mentioned above are already making headway in this respect. We can see a shift here away from the macroanalysis of women and employment which characterised a good deal of second wave feminist scholarship, towards various micrological studies of gendered careers and pathways, in and through the creative and precarious sector. My argument with regard to future feminist approaches to gender and precarious work has been that it is imperative to explore the actual points of tension - the levels of anxiety, the new realms of pain and injury - which accrue from the excessive demands of these multi-tasking careers. Is the potential for new collectivity to be found at such points of break-down, or at points where exit seems like the only option? Might there also be a generational dynamic here, when women in these sectors reach middle age, and no longer have the appetite for the after-hours networking? ${ }^{48}$

Feminist contributions to this kind of debate have been characterised by an emphasis on actual working practices, which is in sharp contrast with Hardt, Negri et al, who are explicit in their desire to bring post-Marxist philosophy together with a futuristic agenda for new radical labour movements, leaving little space for anything like a case study or even references to career pathways or to the actual experiences of working life in these sectors. The nearest they come to this is in the case of Lazzarato who works with the Paris based 'Les
47. Gilroy, There 'Aint No Black in the Union Jack, op. cit.

48. See the ongoing work of Zoe Romano at $<$ www.edufashion. org $>$ and at $<$ www. openwear.org $>$. 
49. P. Virno, The Grammar of the Multitude, New York, Semiotexte, 2005. An equally interesting example from Italy can be seen at <www. casainternazionale delledonne.org $>$.
Intermittents Du Spectacle' campaigning for union rights, but the references to this project are fragmented. Virno, looking backwards historically, mentions in passing the Milan Womens' Bookstore of the 1980s as an example of cooperative working, where collective values and responsibility to the community took precedence over the market. It is ironic then that when looking for alternative working subjectivities and practices which are not wholly captured by the logic of the speeded-up, postmodern creative industries, it is a feminist bookshop which springs to mind. Such experiments defined themselves in terms of the pleasures of work done for the sake of it, rather than through other indexes of commercial success. ${ }^{49}$ I find this an apt point to draw together various of the strands I have tried to grapple with in the course of this essay. The generation of writers who make up the Operaismo group come from the late 1960s and early '70s waves of activism and violent as well as non-violent opposition to state repression. However, alongside the more dramatic confrontations of that time there were also thousands of projects and small businesses set up as part of the 'alternative society'. From feminist publishing houses, 'women into manual trade' co-ops, radical day-care centres for children, girls groups and 'maedchenarbeir' in Germany, to many other forms of self-organised economic activity such as women's photography workshops, these social enterprises provide perhaps a stronger model for co-operation, job creation and for the re-kindling of the idea of socially valuable work than what is currently available within the frame of the new creative industries. Such models also, despite all kinds of internal ideological conflicts, established the possibility of a radical politics of the workplace which fitted with the constraints and the culture of the small enterprise. The women who set up these kinds of ventures were multi-taskers avant la lettre; they also inhabited the long-hours culture and were more than passionately attached to their work. It is this kind of historical perspective which is also missing from contemporary debate on gender and affective labour. 